\title{
Research Paper \\ Meta-analysis of the Effectiveness of Therapeutic-Educational Interventions on the Improvement of Specific Learning Disorder
}

\section{Marjan Manavi Shad ${ }^{1}$, Javad Mesrabadi*2, Ramin Habibi Kelibar ${ }^{3}$, Abolfazl Farid ${ }^{3}$}

1. Ph.D. Student of Psychology, Faculty of Educational Sciences and Psychology, Azarbaijan Shahid Madani University, Tabriz, Iran 2. Professor, Department of Educational Psychology, Faculty of Educational Sciences and Psychology, Azarbaijan Shahid Madani University, Tabriz, Iran

3. Associate Professor, Department of Educational Psychology, Faculty of Educational Sciences and Psychology, Azarbaijan Shahid Madani University, Tabriz, Iran

Citation: Manavi Shad M, Mesrabadi J, Habibi Kelibar R, Farid A. Effectiveness of emotionally focused couple therapy on cohesion, adaptability, emotional intimacy and quality of communication in the parents after the birth of the first child. Quarterly Journal of Child Mental Health. 2020; 7(3): 264-277.

http://dx.doi.org/10.52547/jcmh.7.3.21

A R T I C L E I N F O

\begin{tabular}{l}
\hline Keywords: \\
Specific learning \\
disorder, \\
meta-analysis, \\
therapeutic-training \\
interventions
\end{tabular}

Received: 2 Oct 2018

Accepted: 11 Feb 2019

Available: 7 Dec 2020

\section{A B S T R A C T}

Background and Purpose: Researchers and practitioners in the field of specific learning disabilities have applied different therapeutic methods in their experimental and quasi-experimental studies to help individuals with this disorder and to solve their academic problems. Current study, using metaanalysis methodology, aims to investigate the effectiveness of therapeutic-training interventions on the improvement of specific learning disorder.

Method: This meta-analysis study included all the national researches available in the area of therapeutic-training interventions done for specific learning disorder, published during 2001 to 2014. To achieve these researches, the database of the Academic Center for Education, Culture and Research, Magiran database, and the website of human sciences were searched. To select the initial studies, the keywords of specific learning disorder, learning disability, math learning disability, reading disability, writing disability, spelling disorder, dyslexia, dysgraphia, Davis method, Fernald method, Kephart, training interventions, and psychological interventions were used. To determine the effect size of the therapeutic-training interventions, 33 effect sizes were selected by convenience sampling out of the 24 researches accepted and the meta-analysis was done on them. Study tool was meta-analysis checklist.

Results: Findings showed that the effect size of therapeutic-training interventions on the improvement of specific learning disorder was 0.75 which is considered a high value as per Cohen's table. Results also indicated that the effect size of Fernald therapeutic technique was higher than the two other methods (practice and repeat and multi-media) which had the effect sizes of 0.87 and 1.32 , respectively.

Conclusion: The effect size obtained shows the effectiveness of therapeutic-educational interventions on the improvement of specific learning disorder. Also, regarding the results of this study indicating the greatness of the effect size of Fernald multi-sensory technique, it can be concluded that multi-sensory techniques that pay attention to different problems of students with specific learning disorder should be prioritized in designing therapeutic programs for these students.

\footnotetext{
* Corresponding author: Javad Mesrabadi, Professor, Department of Educational Psychology, Faculty of Educational Sciences and Psychology, Azarbaijan Shahid Madani University, Tabriz, Iran.

E-mail addresses: Mesrabadi@gmail.com
} 


\section{فراتحليل اثربخشى مداخلات درمانى - آموزشى بر بهبود اختلال ياد كيرى خاص}

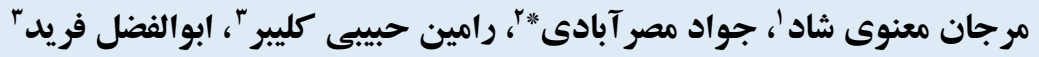

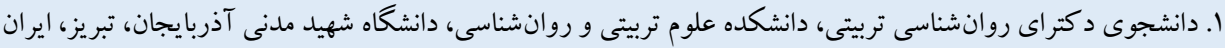

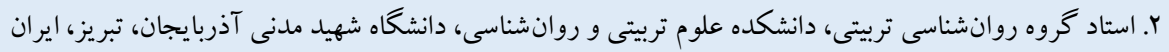

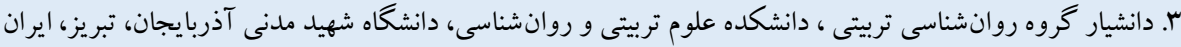
مشخصات مقاله

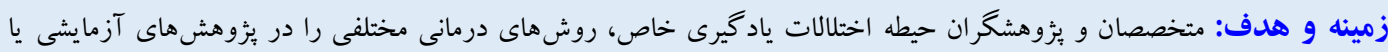

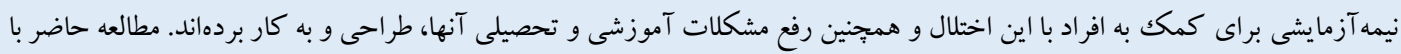

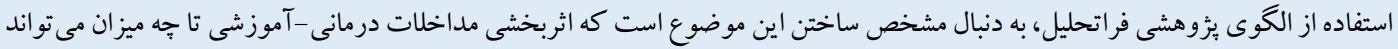
در بهبود اختلال ياد كيرى خاص اثر كذار باشد.

جكيده

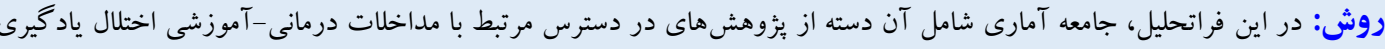

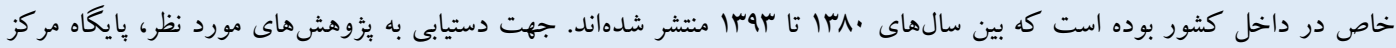

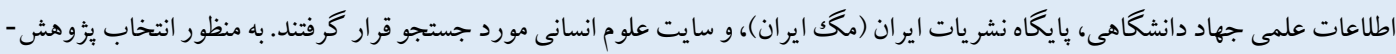

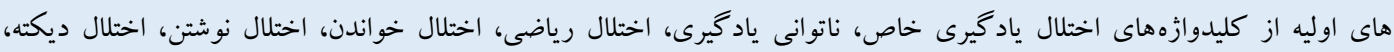

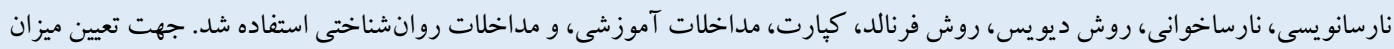

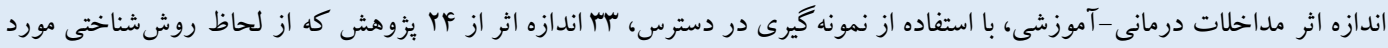

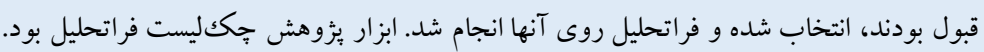

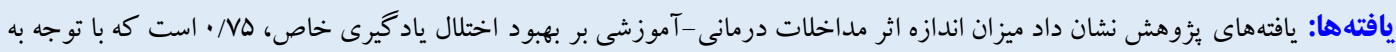

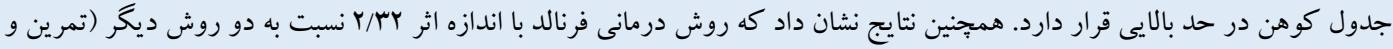

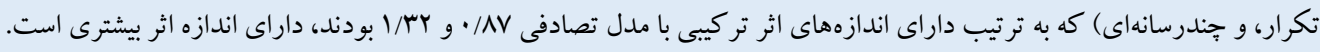

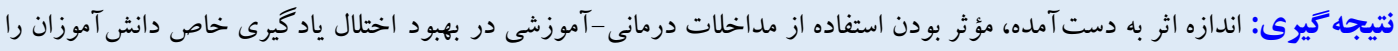

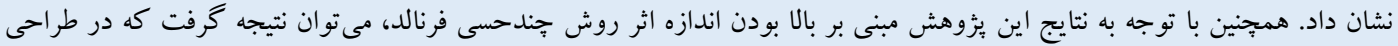

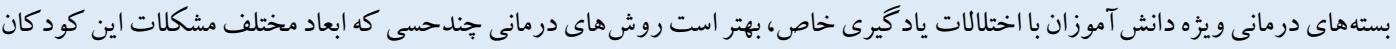

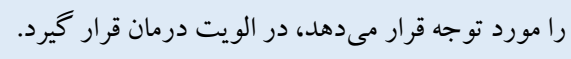

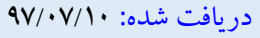

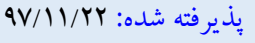
منتشر شده: 99/IV

* نويسنده مسئول: جو اد مصر آبادى، استاد گروه روانشناسى تربيتى، دانشكده علوم تربيتى و روانشناسى، دانشكاه شهيد مدنى آذربايجان، تبريز، ايران.

Mesrabadi@gmail.com :رايانامه

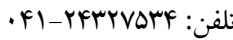


مىشـود، مشـكلات هجى كردن، اشـكال در بيان نوشـتارى، اشـكال در مقلدمه

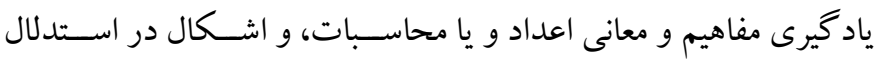

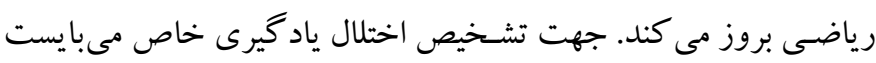

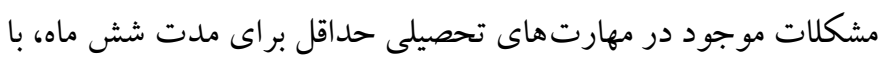
وجود انجام مداخلات درمانى براى رفع مشكلات، تداوم داشته باشند. از آنجايى كـه مشـكلـات موجود در اين اختلال، مربوط به كم توانى ذهنى (بهره هوشى بالاتر از •Vدارند)، تاخير كلى تحولى '، مشكلات بينايى يا

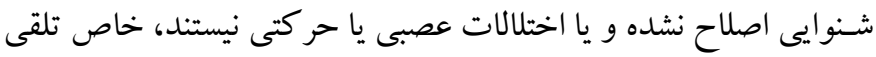

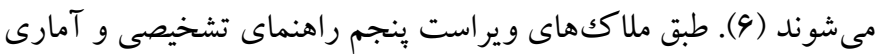

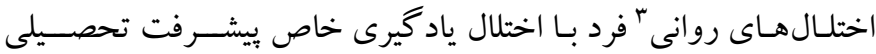
متفاوتى با همسالان دارد؛ حالتى كه برخى صاحبنظر ان به آن "يشرفت

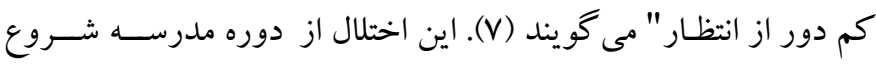

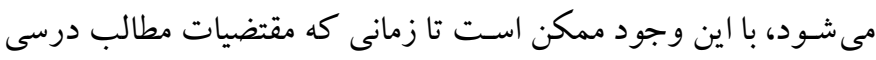

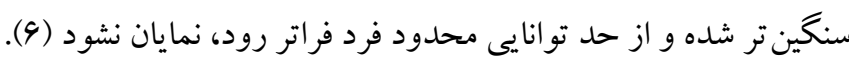

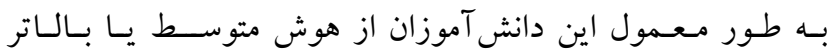

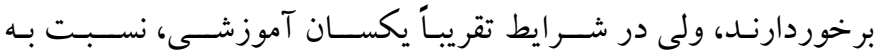

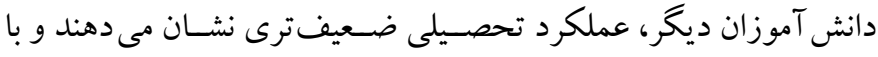

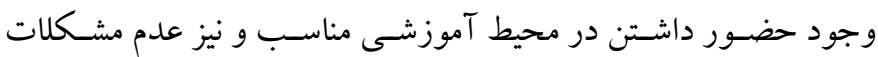

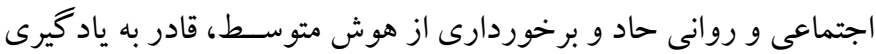
در زمينهاى خاصى تحصيلى (خواندن، نوشستن، و رياضى) نيستند (A). مهارت اساسى كه در دوره ابتدايى بايد كسب شود مهارت در محاسبه و

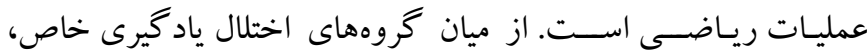
دانش آموزان با اختلال ياد گيرى رياضسى، بِ بس از نارسـاخوانى دومين

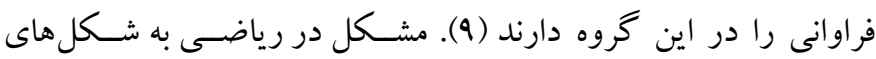

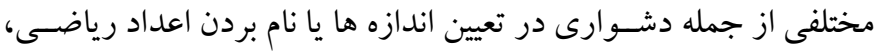
ناتوانى در شـمردن، مقايسـه كردن، و محاســبات ذهنى و عملى نمايان

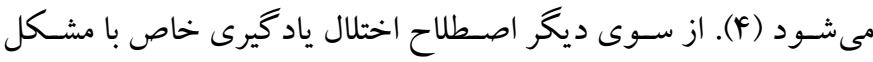

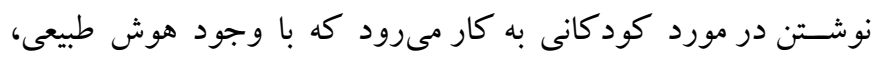
بسـيار بد مىنويسـند. بر اسـاس بنجمين راهنماى تشـخيصسى و آمارى

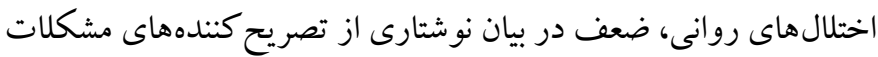

از اهداف نظامهاى آموزشى، بالابردن سطح توانايى دانش آموزان جهت

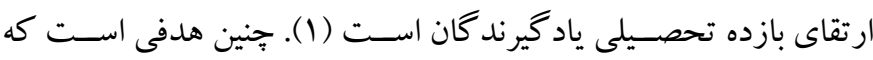

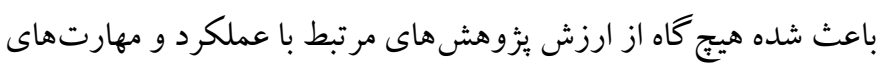
درسى كاســته نشود و باوجود افزايش كشاكشها در تعريف كودكى اسـتثنايى و همجنين افزايش سا درصدى جمعيت دانش آموزان استثنايى

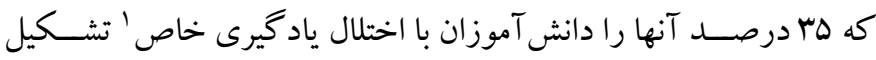

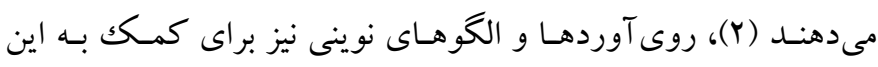
جمعيت گسترده مطرح شود.

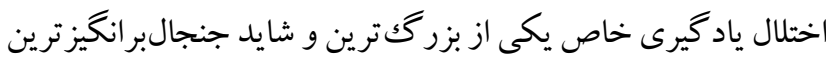

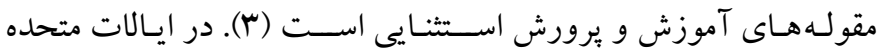
آمريكا، اختلال يادگيرى خاص اصطلاحى براى توصيف كود كانى است

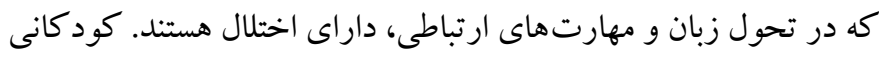

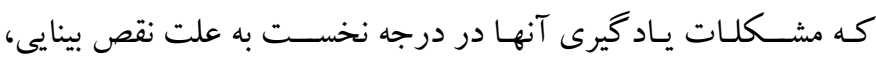

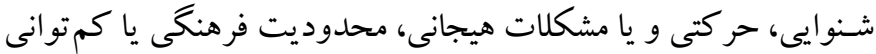
ذهنى كلى است، جزء اين خروه محسو ب نمىشوند (F). به علت اهميت اختلال ياد گيرى خاص شــاسـيى، تشخيص و درمان به موقع آن به منزله

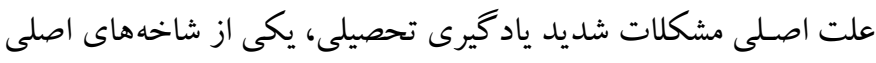
روانشناسى و آموزش و يرورش كود كان استثنايى و روانشناسى تربيتى محسوب مى شود. همان طور كه تو انايى هوشى و موفقيتهاى تحصيلى

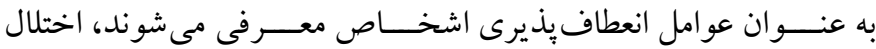
ياد گيرى خاص مى تواند عامل آسيبذيذيرى فرد باشد (ه).

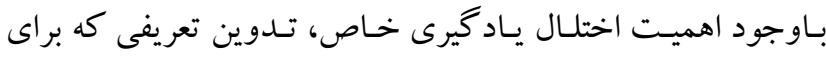

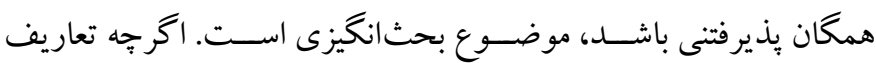

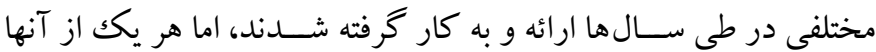

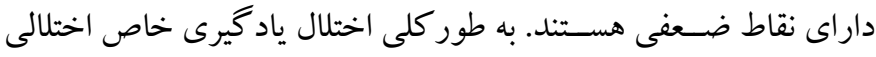
عصبى تحولى با منشأ زيستى است كه موجب نابهنجارى ها يى در سطح

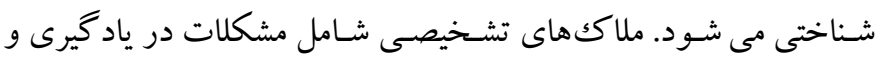

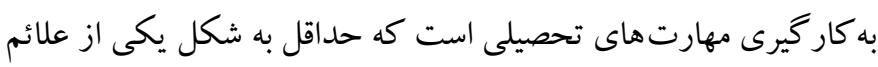
روانخوانى دشوار، كند و نادرست، اشكال در درك معنى آنجه خوانده 
از روش فراتحليـل نشــان دادنـد كه كود كان با و بدون اختلال ياد گيرى خـاص از لحـاظ فراينـدهـاى شــــاختى (f())، حـافظـه فعـال (ها)، و كار كردهاى رفتارى و شـناختى (19) با هم تفاوت دارند. فراتحليل بهبود

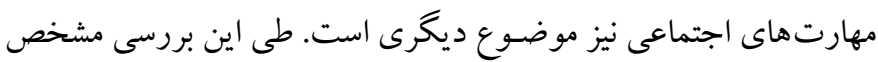
شـــه كـه آموزشهـاى ترميمى و درمـانى مبتنى بر افزايش مهارتهاى

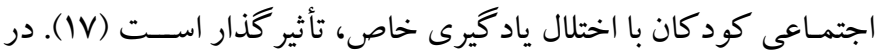
ايران يزووهش فراتحليلى شمسى، عابدى و صمدى و احمدزاده نشان داده

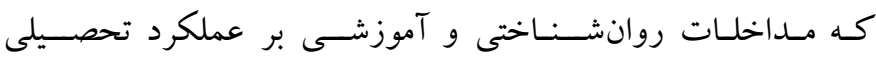

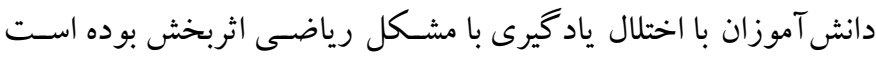
(IN). به همين ترتيب سيادتيان و قمرانى طى بثزوهش خود كه بر مبنـــاى

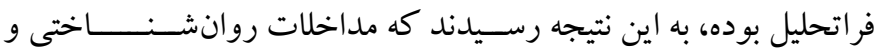

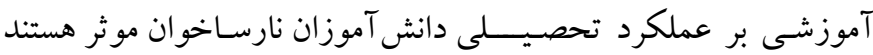

با توجه به وجود روش هاى مختلف آموزشـى و درمانى كه با هدف بهبود عملكرد دانش آموزان با اختلال ياد گيرى خاص مورد مود اسـتفاده قرار

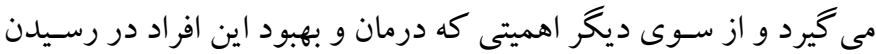

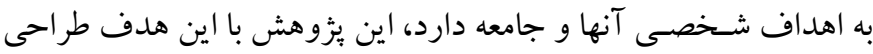
شد تا اندازه اثر اثربخشى مداخلات درمانى -آموزشى را بر بهبود اختلال التهال

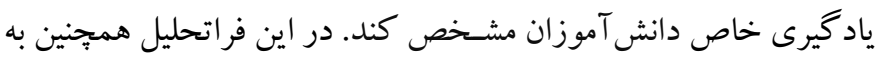

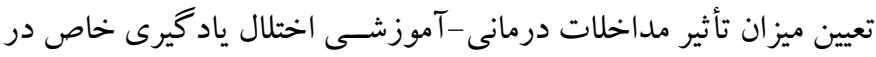
يُزوهش هاى آزمايشسى و شــبه آزمايشـى و همجنين ميزان اندازه اثر در

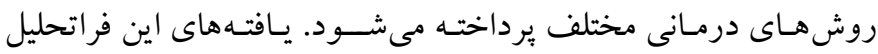

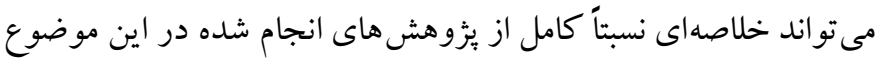
را براى متخصصان حوزه اختلال ياد گيرى خاص فر اهم كند.
ياد گيرى ويزه اسـت كه بر اين اسـاس شامل ويزگ گى هايى جون مشكلات

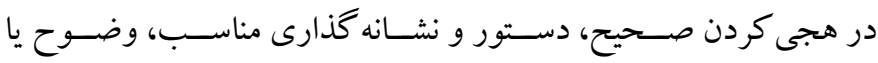

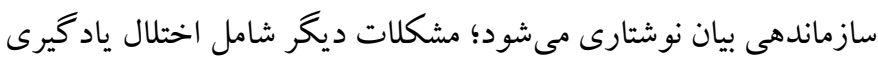

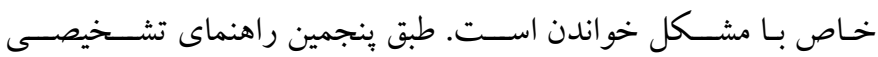
اختلال هاى روانى، نارسايى در خو اندن با دقت در خواندن كلمه، سرعت و روانخوانى، و در كك مطالب خو انده شده مشخص مى شود (9). در كل نتايج مطالعات بيانكر آن اسـت كه فرواوانى اختلال يادگيرى خاص تقريباً در ها تا و درصد كل جمعيت است (· (1). مو كاسيل، وياتيل،

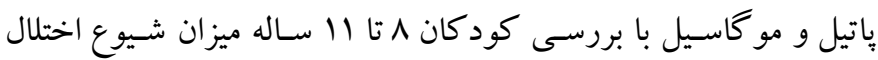

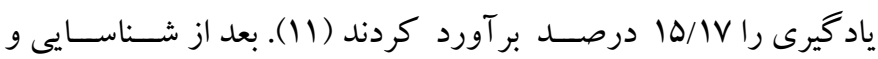
تشخيص اختلالات يادگيرى، بايد به درمان و كمكك به فرد مبتلا در جهت أنه

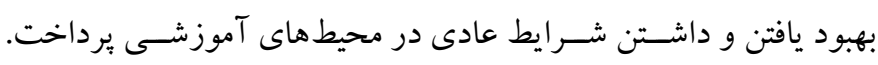

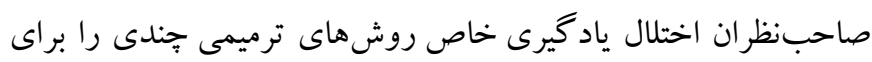

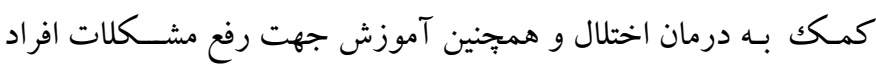

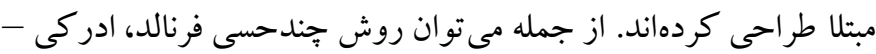

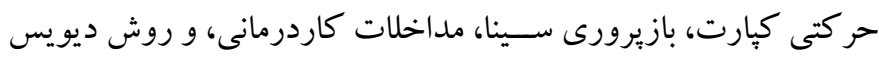

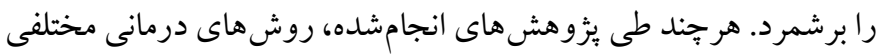

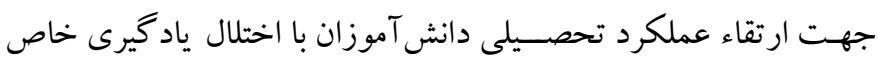

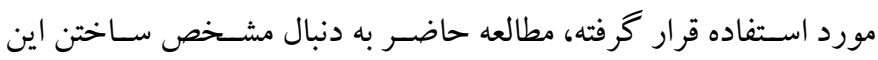
موضـوع اسـت كه مداخلات درمانى -آموزشسى تا جه ميزان مى تواند در

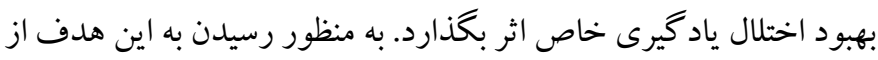
روش فراتحليل استفاده شده است. در خارج از كشور بررسىهايى براى مشخص كردن تأثير مداخلات

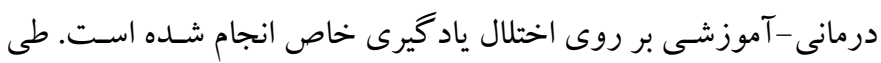

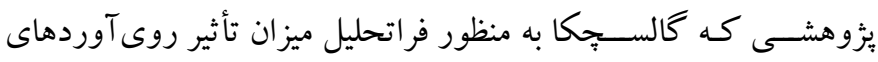

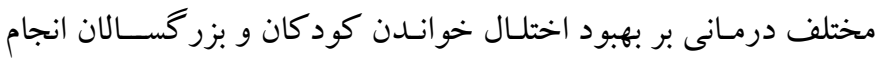

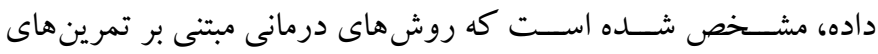

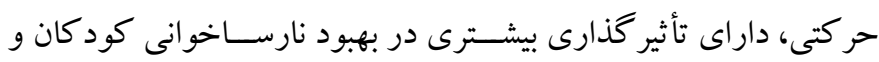

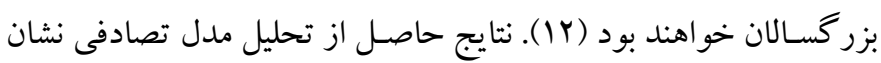

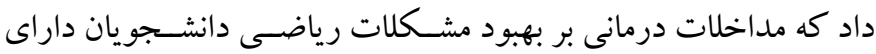

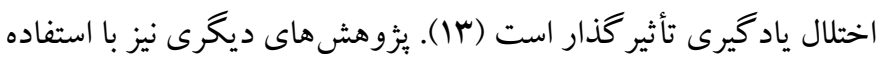


كفته شـده به شناسايى DV مطالعه منجر شد. از آنجايى كه تعدادى از اين مطالعات براى ورود به تحليل نهايى مناسب نبودند، با توجه به ملاككهاى خروج از فرايند تحليل خارج شدند. ملاككهاى خروج شـامل نداشـتن اطلاعات للازم براى محاسـبه اندازه اثر، همجنين يثوهش هـاى ارســال شـــه به دو مجله مختلف، و مقالات داراى ضسعف هاى روششـناختى جدى بود. بر اسـاس ملاككهاى خروج

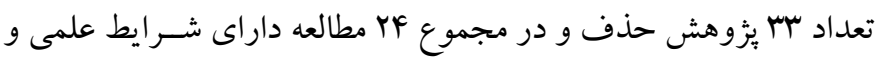

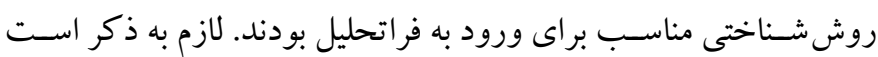

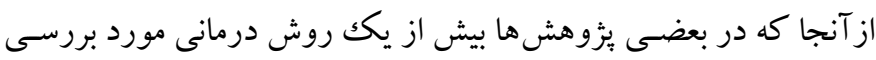

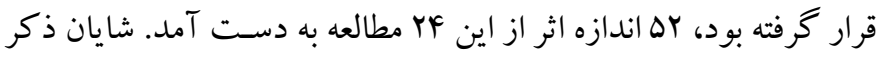

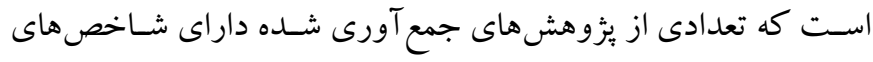

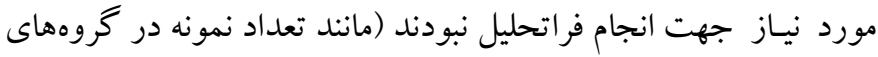

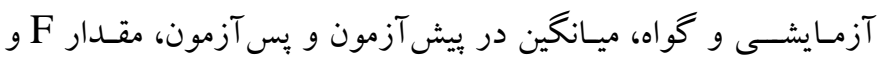

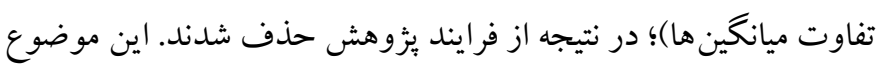
از محدوديت هاى اين يثزوهش محسـوب مى شـود كه بيشــهاد مى شــود

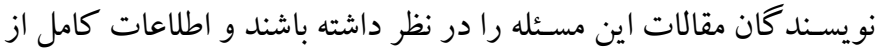
فر ايند يُزوهش را در مقالات خود درج كنند. همجينين تعدادى از مقالات

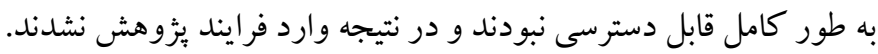

\section{يافتهها}

جهت تحليل دادهها از اندازه اثر جى هـز بر براى هر يزٔوهش اوليه، اندازه اثر تركيبى بـا دو مـدل اثرات ثـابـت و تصـــادفى، نمودار قيفى، تحليـل

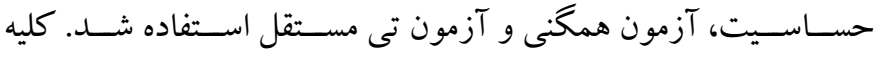
محاسبات مربوط به فراتحليل با استفاده از نرم افزار سى. ام. اى و جهت بررسـى معنادارى تفاوت اندازههاى اثر با آزمون تى مسـتقل از نرم افزار

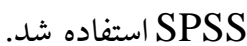

يـاد كيرى خاص در داخل كشــور بود كه بين ســالهاى هربا تا سوه|

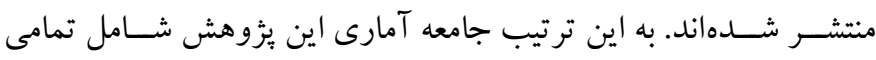

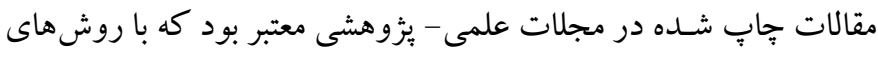

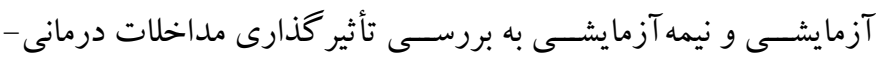

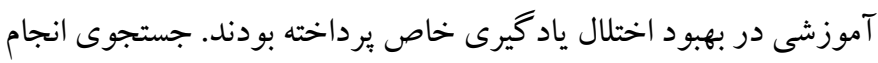
شـــه به شــناسـايى هV مطالعه منجر شـــــ از آنجايى كه تعدادى از اين مطالعات براى ورود به تحليل نهايى مناسب نبودند، با توجه به ملاككهاى

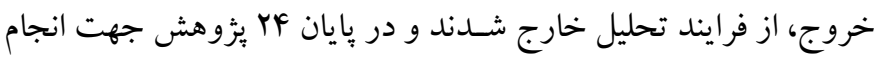
فر اتحليل انتخاب شدند.

جهـت انتخاب يزوهش هاى اوليه ابتدا كليدوازههاى يزوهش انتخاب شدند. اين متغيرها شامل اختلال يادگيرى خاص، ناتوانى يادگيرى، اختلال

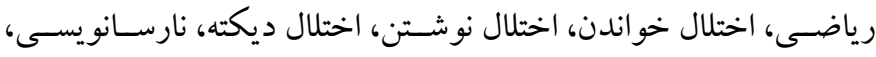

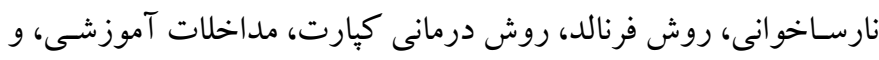
مداخلات روانشــناختى بود. در مطالعه حاضــر فقط ئزوهشهاى داخل

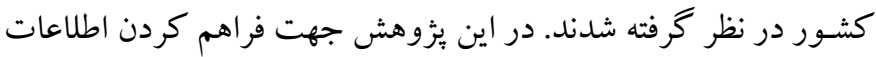

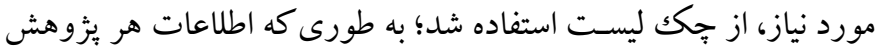

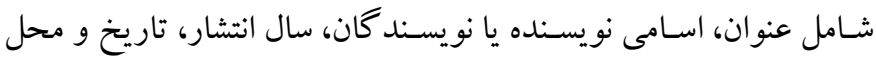

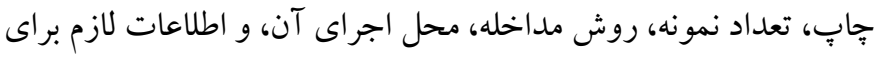

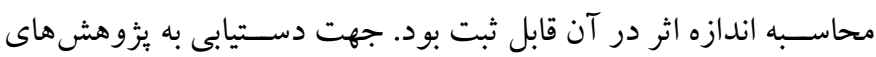

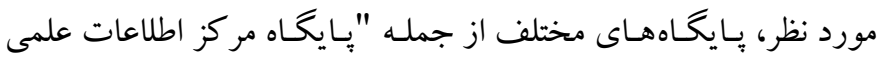

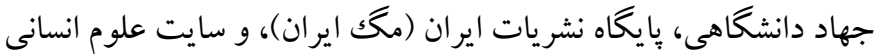
مورد جستجو قرار گرفتند.

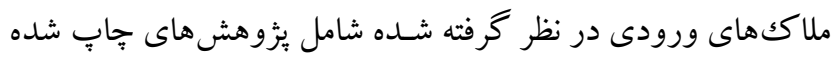

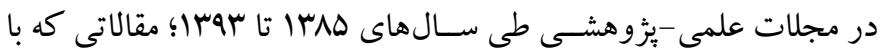
روش آزمايشى يا شبه آزمايشى به بررسى مداخلات درمانى - آموزشى

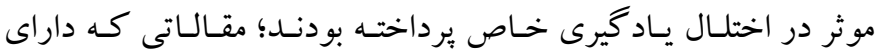
دادههاى كافى براى محاسبه اندازه اثر بودند. جستجو بر طبق ملاككهاى يرد 


\begin{tabular}{|c|c|c|c|c|}
\hline 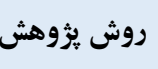 & نمونه & 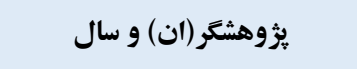 & 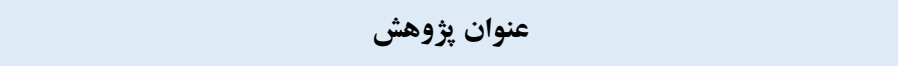 & $\underbrace{\varepsilon}$ \\
\hline 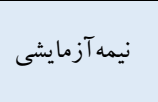 & 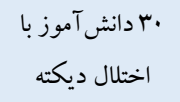 & 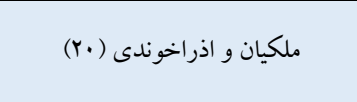 & تأثير جندرسانهاى آموزشى در درمان اختلال املا دانش آموزان ويزّه ياد گيرى شهر كرمانشاه & 1 \\
\hline آزمايشى & 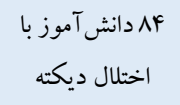 & 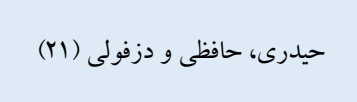 & بررسى تأثير و مقايسه دو روش درمانى جندحسى فرنالد و ادراكى حر كتى كهارت در كاهش & $r$ \\
\hline 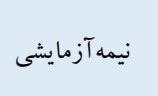 & 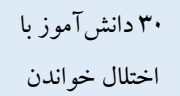 & 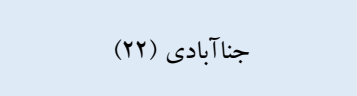 & بررسى تأثير روشهاى بازيرورى كيارت و سينا در درمان اختلال خواندن & $r$ \\
\hline آزمايشى & اختال دانش ديكته آموز با دانش & شهنى، كرمى، شكر كن و مهرابىزاده & 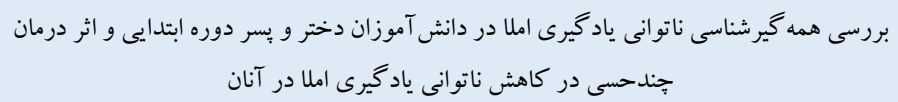 & r \\
\hline 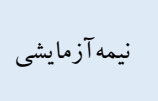 & 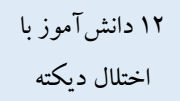 & $\begin{array}{c}\text { نورىزاده، ميكايلى، رستمى و صادقى (YF) } \\
\text { و (Y) }\end{array}$ & اثر بخشى نوروفيدبكك بر اختلال يادگيرى همر اه با نارسايى توجه/ فزون كنشى & $\Delta$ \\
\hline 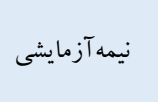 & 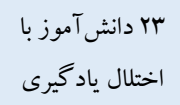 & $\begin{array}{c}\text { ماندنى، سازمند، فرهبد و كريملو } \\
\text { (YD) }\end{array}$ & تأثيرات مداخلات كاردرمانى بر يكهار خكى بينايى - حركتى كود كان با اختلال ياد گيرى & 4 \\
\hline آزمايشى & 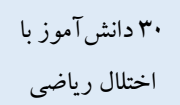 & 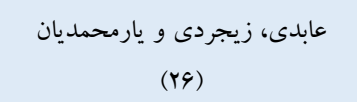 & اثربخشى آموزش توجه بر عملكرد رياضى دانش آموزان با ناتوانى يادگيرى رياضى & v \\
\hline نيمه آزمايشى & 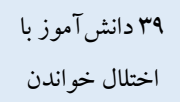 & 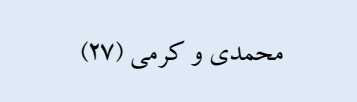 & بررسى ميزان اثربخشى رويكرد جندحسى فرنالد در درمان مشكل ويزه خواندن & $\wedge$ \\
\hline آازمايشى & 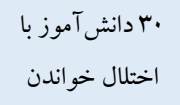 & 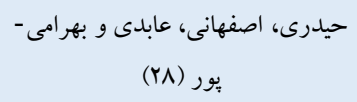 & مقايسه اثربخشى روش فرنالد و ديو يس بر عملكرد خو اندن دانش آموزان نارساخوان & 9 \\
\hline 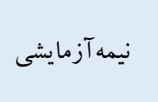 & 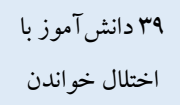 & محمدى، كرمى و هاشمى (rq) & تأثير آموزش جندحسى فرنالد و تمرين و تكرار در بهبود اختلال ويزه ياد گيرى خو اندن & 1. \\
\hline آازمايشى & 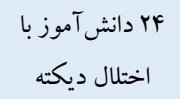 & منصورنزاد، كجباف و مولوى (r) & تأثير آموزش קجندحسى فرنالد بر نارسـانويسى و املانويسى در دانش آموزان پايه دوم ابتدايى & 11 \\
\hline آازمايشى & اختلاJ رياضى دانش آموز با & محمدى، كرمى و بيرامى (آم) & بررسى ميزان اثربخشى رويكرد تكليفمدار در درمان ناتوانى ويزه يادگيرى رياضى & Ir \\
\hline آزمايشى & 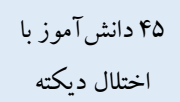 & آقابابايى، ملككيور و عابدى (rr) - Ir) & اثربخشى آموزش كار كردهاى اجرايى بر عملكرد تحصيلى كودكان با ناتوانى يادكيرى املا & Ir \\
\hline 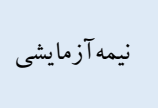 & r آدانش آموز با & عبداللهى، كيان و رحيميان (Tr) & 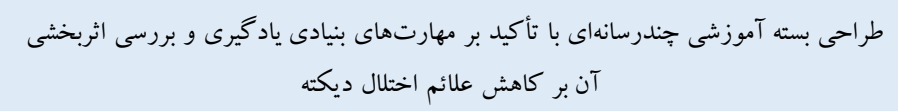 & If \\
\hline آازمايشى & 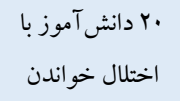 & 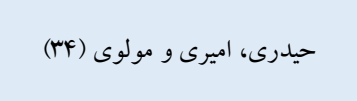 & اثربخشى روش تصحيح نارساخوانى ديو يس بر عملكرد خواندن كود كان نارساخوان & 10 \\
\hline 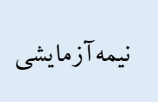 & 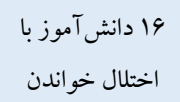 & شايان، اخوان تختى و عشايرى (ها) & تأثير روش ترميمى ديويس بر بهبود نار ساخوانى & 19 \\
\hline آمايشى & 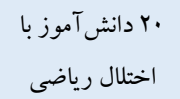 & ياورى، ياريارى و رستگاريور (4) & بررسى اثربخشى نرمافزار آموزشى حسابيار بر يادگيرى رياضيات دانش آموزان حساب نارسا & IV \\
\hline 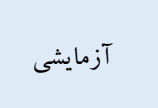 & 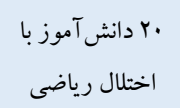 & استكى، دلاور، عشايرى و تبريزى & مقايسه اثربخشى آموزش دو نيمكره مغز و آموزش موسيقى در عملكرد حساب نارسايى دانش - & 11 \\
\hline 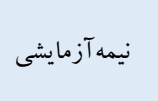 & 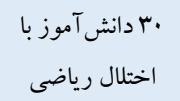 & 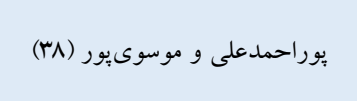 & توليد جندرسانهاى آموزشى حساب آموز و اثربخشى آن بر ييشرفت تحصيلى عمليات تفريق و & 19 \\
\hline
\end{tabular}




\begin{tabular}{|c|c|c|c|c|}
\hline آزمايشى & 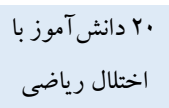 & 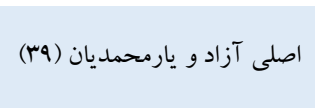 & اثر آموزش فراشناخت و روابط فضايى بر عملكرد رياضى كودكان دجار ناتوانى يادگيرى & $r$. \\
\hline آزمايشى & 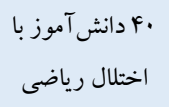 & خدامى، عابدى و آتشيور (F. ) خ (F) & اثربخشى آموزش كاركردهاى اجرايى، بر بهبود عملكرد دانش آموزان با ناتوانى يادكيرى & YI \\
\hline آزمايشى & 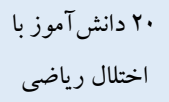 & يارمحمديان و اصلى آزاد (Fا) (F) & اثربخشى آموزش فراشناخت بر بهبود عملكرد رياضى كودكان با ناتوانى يادگيرى رياضى & Yr \\
\hline 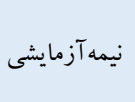 & 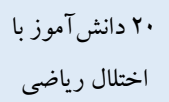 & غبـارى، نصـرتى، غلامحسينزاده & تأثير روش خودآموزى بر عملكرد حل مسئله رياضى دانش آموزان اختلال رياضى & זr \\
\hline آزمايشى & هب دانش آموز با اختلال ديكته & عظيمى و موسوى يور (Fr) & 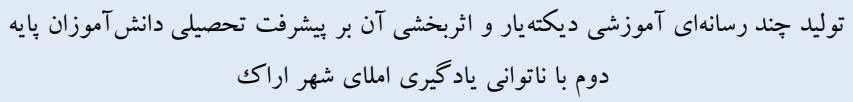 & YF \\
\hline
\end{tabular}

$$
\begin{aligned}
& \text { جدول ا شــامل اطلاعات عمومى YF يزوهش اوليه، طى سـالهاى }
\end{aligned}
$$

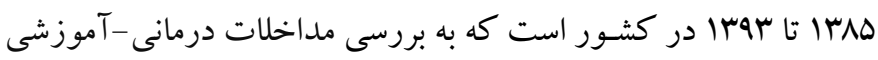

$$
\begin{aligned}
& \text { بر بهبود اختلال ياد گيرى خاص دانش آموزان برداختهاند. }
\end{aligned}
$$

جدول r: اندازه اثر يزوهشهاى آزمايشى و نيمه آزمايشى مربوط به روشهاى درمانى اختلال يادكيرى خاص

\begin{tabular}{|c|c|c|c|}
\hline اندازه اثر & مطالعات & اندازه اثر & مطالعات \\
\hline.$/ 10$ & محمدى، كرمى و بيرامى (Iاس) & $\cdot / \mu F$ & ملكيان و آذر آخوندى (r) \\
\hline$\cdot / \mu$ & محمدى، كرمى و بيرامى (ابس) & $\cdot / r$ & ملكيان و اذراخوندى (r) م) \\
\hline$\cdot / 94$ & محمدى، كرمى و بيرامى (اس) & $* / 94$ & حيدرى، حافظى و دزفولى (YI) \\
\hline$" 1 / 4$. & محمدى، كرمى و بيرامى ( آ) & .190 & جنآبادى (Yr) \\
\hline *T/l. & " محمدى، كرمى و بيرامى (Iاr) & $4 / .9$ & " جنآبادى (Yr) \\
\hline$\cdot / 19$ & محمدى، كرمى و بيرامى (1/) & $T / M$ & شهنى|كرمى شكر كن و مهرابىزاده هنرمند (rr) \\
\hline $4 / \cdot 9$ & " اقابابايى، ملكك يور و عابدى (rr) & $r / 9 V$ & شهنى، كُمى شكر كن و مهر ابىزاده هنرمند (rr) \\
\hline$T / .9$ & " آقابابيى، ملككيور و عابدى (rr) & $\cdot / r V$ & نورىزاده، ميكاييلى، رستمى و صادقى (YF) \\
\hline$T / Y q$ & • عبداللهى،كيان و رحيميان (Tس) & "I/Ar & ماندنى، سازمند، فرهبد، كريملو و ماندنى (YD) \\
\hline$\cdot / T \Delta$ & حيدرى، اميرى و مولوى (YY) & $T / F A$ & • عابدى، زيجردى و يارمحمديان (Y4) \\
\hline "T/VG & ل شايان، اخوان تختى و عشايرى (هr) & Tr/VY & (YV) " محمدى و كرمى \\
\hline "1/V9 & ياورى، ياريارى و رستگاريور (4) & $T / Y F$ & " ل محمدى و كرمى (YV) \\
\hline $1 / \cdot 1$ & ياورى، ياريارى و رستگاريور (4) & $\cdot / 1 r$ & محمدى و كرمى (YV) \\
\hline $1 / H F$ & استكى، دلاور، عشايرى و تبريزى (rV) & $\cdot / \cdot \Delta$ & محمدى و كرمى (YV) \\
\hline$T / V$ & " استكى، دلاور، عشايرى و تبريزى (rV) & $9 / 4 \Delta$ & " محمدى و كرمى (YV) \\
\hline "1/9Y & استكى، دلاور، عشايرى و تبريزى (rV) & $\mathrm{T} / \cdot \cdot$ & ) \\
\hline $1 / 01$ & يوراحمدعلى و موسوى يور (rی) & $" 1 / \wedge$. & حيدرى، اصفهانى، عابدى و بهرامى يور (Y^) \\
\hline$\cdot 194$ & يوراحمدعلى و موسوى يور (r/) & $.1 \cdot 9$ & حيدرى، اصفهانى، عابدى و بهرامى بور (YN) \\
\hline$" 1 / N r$ & اصلى آزاد و يارمحمديان (rq) & $T / \pi$ & - محمدى، كرمى و هاشمى (Yq) \\
\hline $1 / \pi V$ & اصلى ازاد و يارمحمديان (qج) & .1 .9 & محمدى، كرمى و هاشمى (Yq) \\
\hline "T/A. & " خدامى، عابدى و آتش يور (F) & $\cdot / A r$ & محمدى، كرمى و هاشمى (rq) \\
\hline T/VF & " خدامى، عابدى و آتش يور (f) & $\cdot / r Y$ & محمدى، كرمى و هاشمى (Yq) \\
\hline$T / F \mid$ & 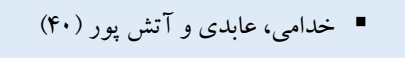 & $\cdot / 94$ & محمدى، كرمى و هاشمى (Y9) \\
\hline "T/MVF & • يارمحمديان و اصلى زاد (FI) &.$/ 81$ & محمدى، كرمى و هاشمى (Y9) \\
\hline
\end{tabular}



$\cdot / \cdots$
غبارى، نصرتى، غلامحسينزاده (Fr)
$M / T V$
منصور نزاد، كجباف و مولوى (r.)
T/990

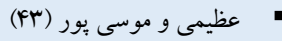
"1/91

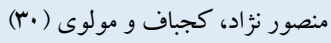

(اندازه اثر معنادار

• مطالعاتى كه داراى تورش انتشار باشند و در ادامه تحليل از جريان فراتحليل خارج شدند.

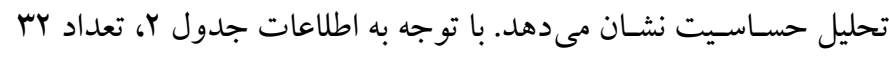

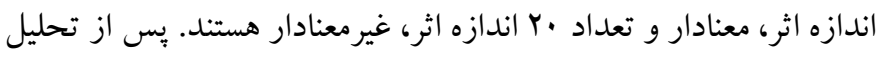
حسـاسـيت، مطالعات داراى سـو گيرى انتشـار (تورش انتشـار) از جريان فراتحليل خارج شدند (19 اندازه اثر) كه با علامت نشان داده شدهاند.

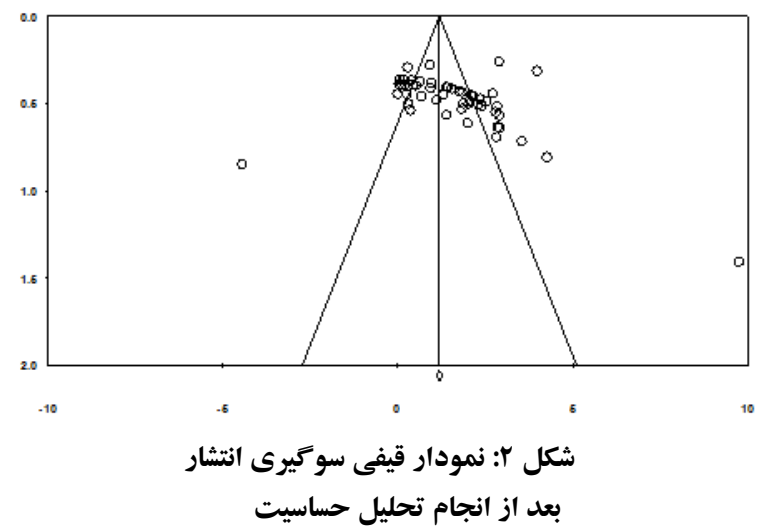

اثر نامتعارف و يرت هستند و اين اندازهها نمودار را نامتقارن ساختهاند. با حذف كردن تدريجى 19 اندازه اثر، نمودار قيفى شكل r حاصل شد كه نسبت به نمودار قيفى شكل ا متقارنتر است. يس از حذف 19 اندازه اثر

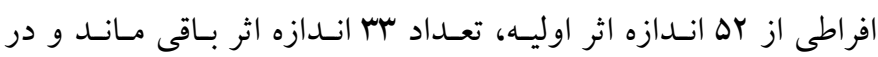
تحليلهاى بعدى از اين تعداد اندازه اثر استفاده شد.
از يثزوهش هاى اوليه (جدول ()، تعداد بـه اندازه اثر محاســبه شــــ. دليـل زيـاد بودن انــازههـاى اثر نســـــت به يزوهش ها، وجود متغيرهاى

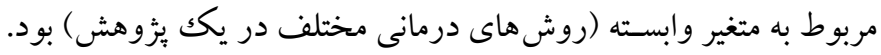

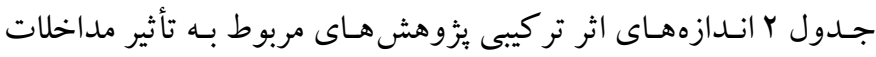

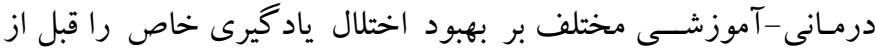

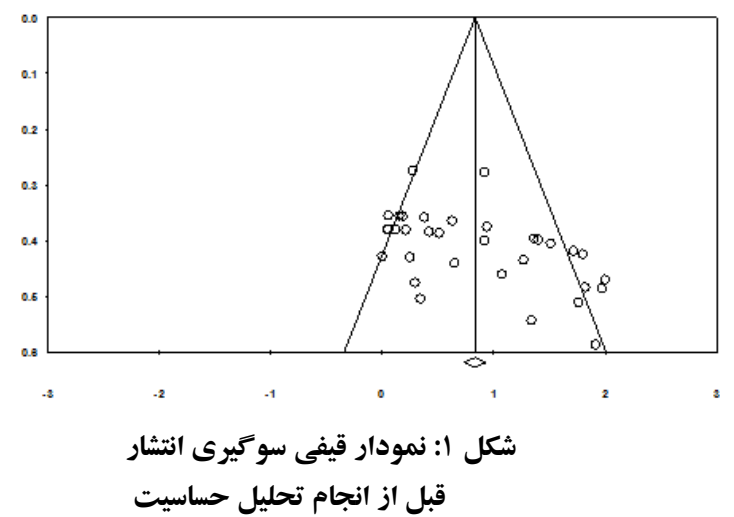

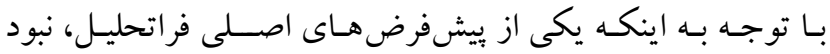

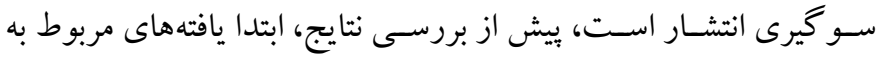

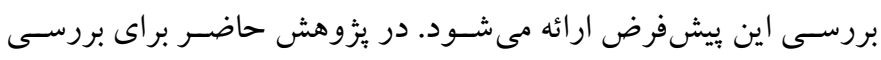

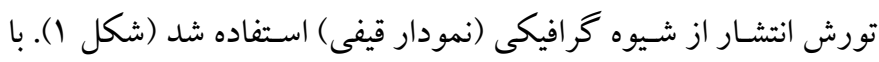
مشـاهده شكل امشخص شد كه تعدادى از يُوهش ها داراى اندازههاى

جدول ץ: اندازههاى اثر تر كيبى اثرات ثابت و تصادفى مربوط به مداخلات درمانى-آموزشى در اختلال هاى يادكيرى

\begin{tabular}{|c|c|c|c|c|c|c|c|}
\hline \multirow{2}{*}{ مقدار P } & \multirow{2}{*}{ Z مقدار Z } & \multicolumn{2}{|c|}{ فاصله اطمينان 90٪\% } & \multirow{2}{*}{ خطاى معيار } & \multirow{2}{*}{ اندازه اثر تر كيبى } & \multirow{2}{*}{ تعداد اندازه اثر } & \multirow{2}{*}{ مدل } \\
\hline & & حد بالا & حد يايين & & & & \\
\hline$\cdot / \cdots$ & $1 \cdot / A r$ & $\cdot / 19$ & .191 & $\cdot / \cdot V$ & $\cdot / V \Delta$ & rr & ثابت \\
\hline$\cdot / \cdots$ & $V / r$. & $1 / \cdot r$ & $\cdot 109$ &.$/ 11$ & $\cdot / \wedge 1$ & r & تصادفى \\
\hline
\end{tabular}

مىشـــد در اين فراتحليل مقـادير اندازههاى اثر تر كيبى حاصسل از سه

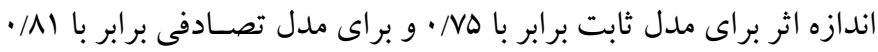

در جدول ب اندازههاى اثر تركيبى يا خلاصه بر اساس دو مدل ثابت و

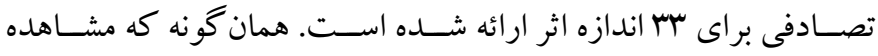


يُروهش هاى اوليه مدل تصـادفى انتخاب مى شـود و فرض مى شود كه در

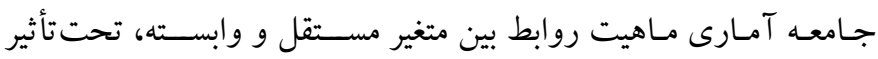
متغيرهاى تعديل كننده تغيير مى يابد.

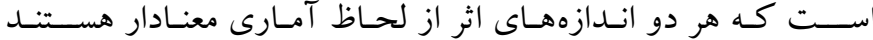

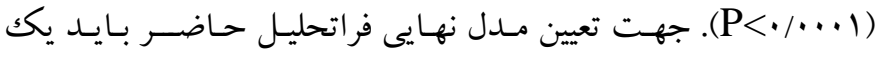

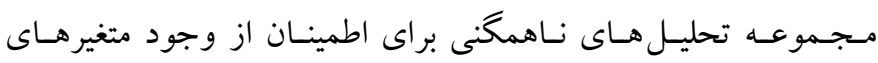

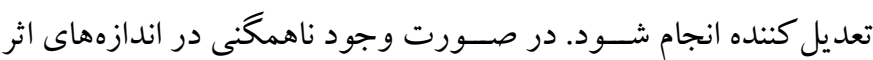

جدول ع: شاخصهاى ناهمكنى اندازههاى اثر در بين بزووهشهاى اوليه

\begin{tabular}{|c|c|c|c|}
\hline سطح معنادارى & درجه آزادى & Iجذور & Qوكران \\
\hline.$/ \cdots$ & $r r$ & $91 / .1$ & $\wedge r / \cdot \wedge$ \\
\hline
\end{tabular}

بنابر اين مدل تصــادفى به عنو ان مدل فر اتحليل انتخاب شـــــ و اندازه اثر تر كيبى همان مقدار |N| • در نظر كرفته شد.

با مشـخص شـدن نقش متغيرهاى تعديل كننده در ادامه به تحليلهاى بيشــر در مورد نقش و شــدت تعامل متغيرهاى تعديل كننده، كه در اين بثزوهش آزمايشى و شبه آزمايشى بود، يرداخته شد. لازم به ذكر است در

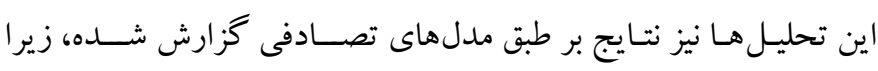
تحليل هاى ناهمگنى نشان داد كه اندازههاى اثر داخل خود اين متغيرهاى تعـــــل كنــده هم ناهمخن هســتند. با توجه به وجود ناهمخنى در داخل ئزوهش هاى اوليه فقط نتايج مربوط به مدل تصادفى ارائهه مىشود.
در جدول F نتايج بررسى ناهمخنى اندازههاى اثر در بين بثزوهش هاى Q كو كران ارائه شـده اسـت. مقدار شاخص Q اوليه بر اسـاس شـاخص

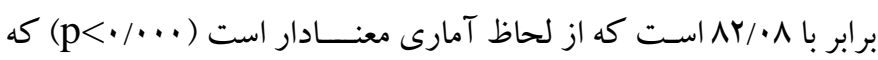
نشـانكر تفاوت واقعى بين انــــدازههاى اثر يزٔوهشهاى اوليه است. نتايج

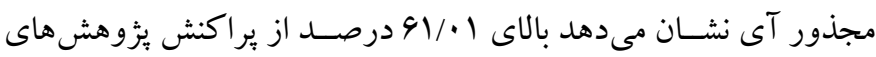
اوليه واقعى و ناشى از وجود متغيرهاى تعديل كننده است كه نشان دهنده و جود ناهمخنى در بثروهشهاى اوليه اسـتـ. بر اســاس هر دو شــاخص نـاهمكنى، مشــخص شــــ كـه متغيرهـاى تعـديـل كنتـده در روابط بين روش هـاى درمـانى و اختلـال يـاد كيرى خـاص نقش معنـادارى دارنـــ و

جدول ه : اندازه اثرهاى تر كيبى با مدل تصادفى و نتيجه آزمون t مستقل دو روش آزمايشى و شبه آزمايشى

\begin{tabular}{|c|c|c|c|c|c|c|}
\hline Pقدار P P & مقدار t & مقدار Z & خطاى معيار & اندازه اثر تركيبى & تعداد اندازه اثر & روش يزوهش \\
\hline \multirow[t]{2}{*}{.$/ \Delta \Delta$} & $r / .9$ & $9 / F F$ &.$/ 19$ & $1 / \cdot r$ & IV & آزمايشى \\
\hline & & $r / 9 \Lambda$ &.$/ 10$ & $\cdot / \Delta \Lambda$ & 19 & شبه آزمايشى \\
\hline
\end{tabular}

مسـتقل استفاده شد. نتايج نشان داد كه تفاوت معنادارى بين ميانخين اين

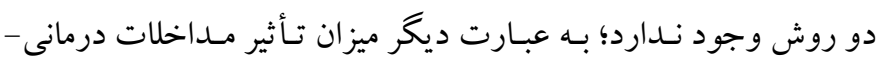
آموزشى اختلال ياد گيرى خاص در يزوهش هاى آزمايشى و شبه آزمايشى

اختلاف معنادارى ندارد.
اندازه اثر تر كيبى با مدل تصـادفى نشـان داد در يزوهش هاى با روش آزمايشسى ب•/1 اسـت، درحالى كه در بزوهش هاى شـبه آزمايشسى مقدار

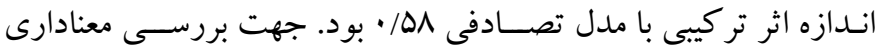
تفاوت در اندازه اثرهاى مشـاهده شده اين دو نوع ئزوهش از آزمون تى

جدول ج : اندازه اثرهاى تركيبى سه روش فرنالد، تمرين و تكرار و جندرسانهاى

\begin{tabular}{|c|c|c|c|c|c|}
\hline مقدار P & مقدار Z & خطاى معيار & اندازه اثر تر كيبى & تعداد اندازه اثر & روش درمانى \\
\hline.$/ \cdots$ & $F / 9 F$ &.$/ A V$ & $r / r r$ & 11 & فرنالد \\
\hline$\cdot / \cdots$ & $r / r$. & $\cdot / r V$ & $\cdot / \wedge \mathrm{V}$ & 9 & تمرين و تكرار \\
\hline$\cdot / \cdots$ & $F / Y F$ & ا & $1 / r r$ & $\wedge$ & جندرسانهاى \\
\hline
\end{tabular}


علت شرايط متفاوت يُزوهش ها، همجينين تفاوتهاى بين فردى نمونهاى

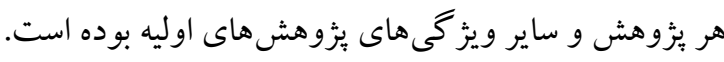

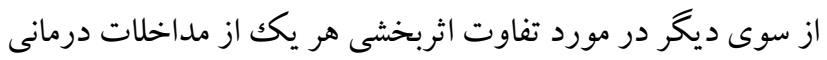

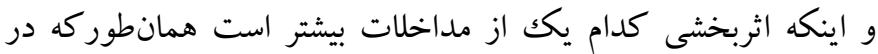
جدول 9 نيز نشان داده شده، روش درمانى فرنالد با اندازه اثر Yr/Y نسبت به دو روش ديخر (تمرين و تكرار، و جندرسانهاى) داراى اندازه اثر

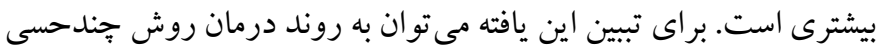

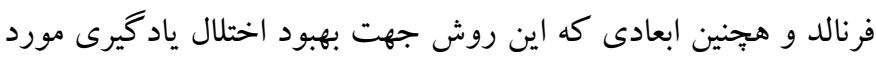
توجه قرار مىدهد، اشاره كرد. جهـت توجيـه نتيجـه بـه دســت آمـده مى توان گفــت از آنجايى كه

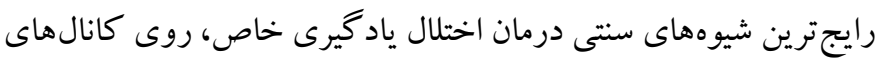

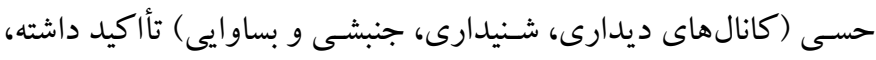
بس روش درمانى فرنالد به عنوان يكك روش درمان جندحسى، اثربخشى

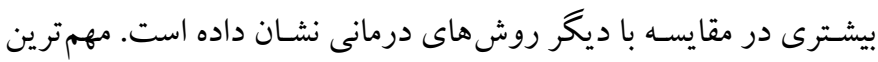
تكنيك در اين روش شيوه ردگيرى است، به اين صورت كه در جريان برنامه آموزشسى شــاكردان كل كلمه را به صــورت يكك واحد بسـيط

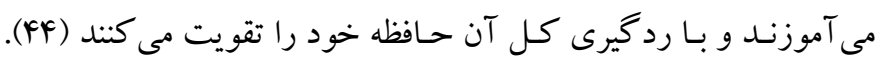

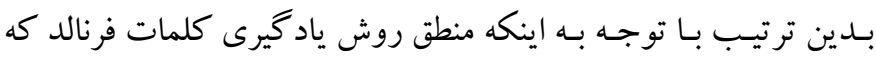

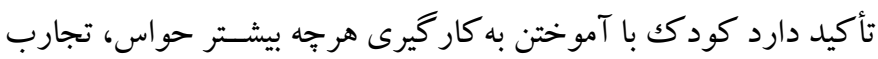

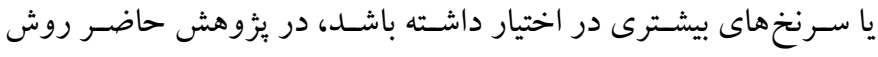
جندحسى فرنالد اثربخشى بيشـترى نسـبت به روش هاى ديخر در درمان

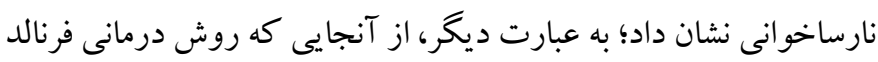
به صـورت جندبعدى به اصسلاح و درمان نقص هاى اوليه و يايهاى اختلال خواندن مى يردازد در درمان اختلال خو اندن، اثربخشى بيشـترى نسبت به

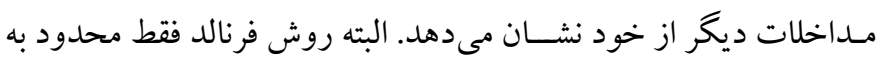

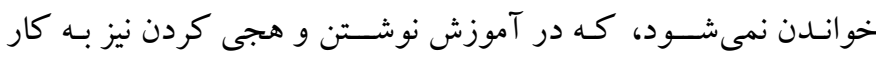

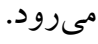

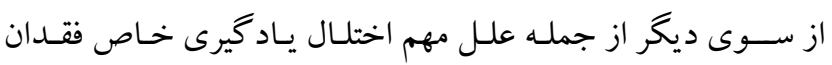

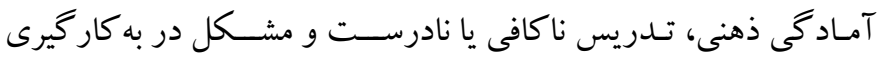

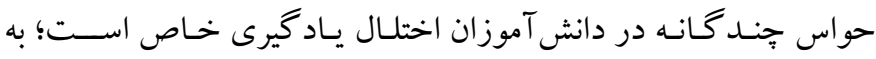

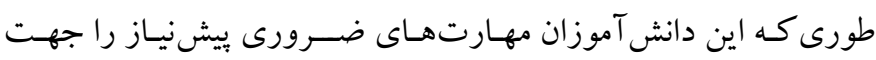

اندازه اثر تركيبى با مدل تصادفى در بثزوهشهايى كه با روش فرنالد

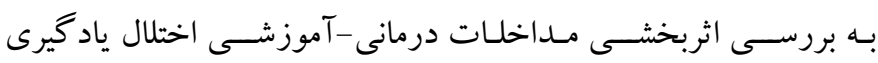
يرداختهاند، Yr/Y است. به همين ترتيب در ئزوهش هايى كه از روشهاى

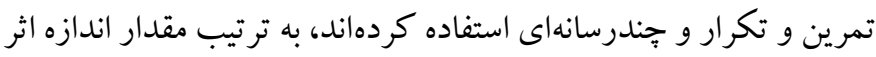
تر كيبى با مدل تصـادفى AV/ • و Yr/1 بود. هر سه اندازه اثر معنادار بودند

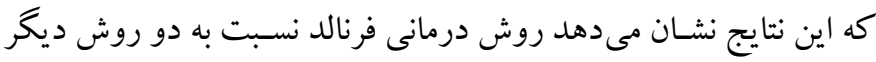

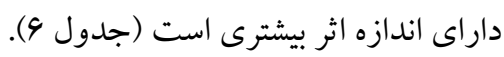

\section{بحث و نتيجه كيرى} هدف بيزوهش حاضر فراتحليل اثربخشى مداخلات درمانى -آموزشى بر

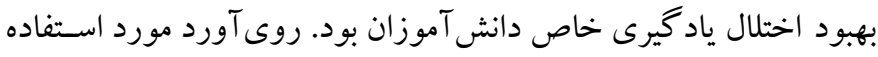

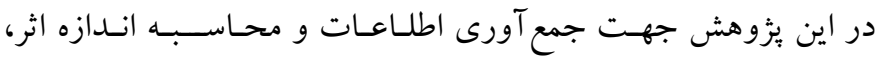

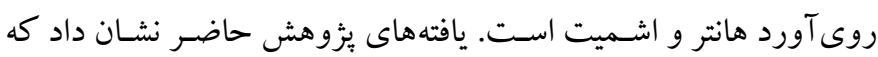

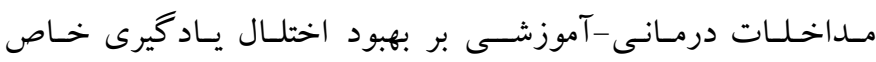

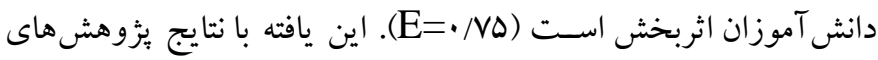

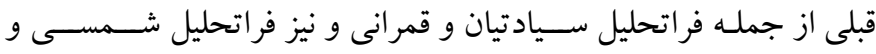

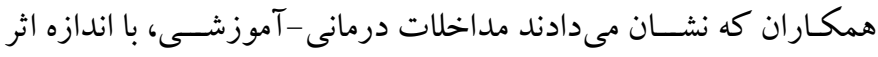

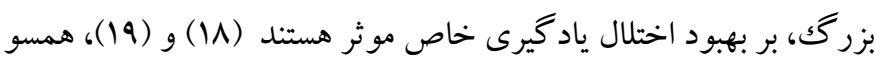

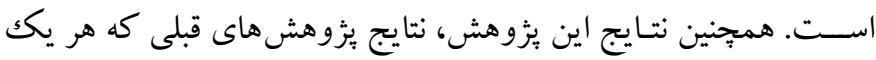
نشـاندهنـده اثربخشـى مــاخلـات درمانى -آهوزشــى بر بهبود اختلال ياد گيرى خاص است و در يزوهش حاضر به عنوان يزوهش هاى اوليه در

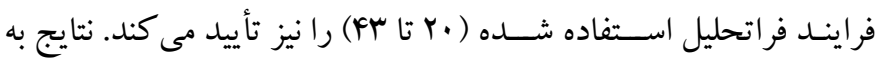
وضوح نشان مىدهد كه مداخلات آموزشى - درمانى اثربخشى مناسبى بر بهبود اختلال ياد گيرى خاص دانش آموزان داشته است.

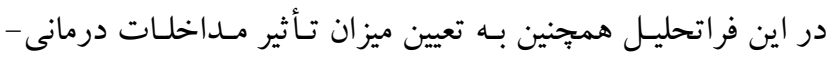

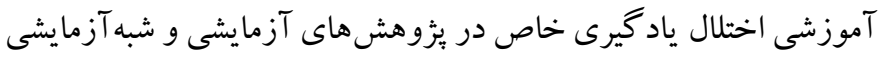

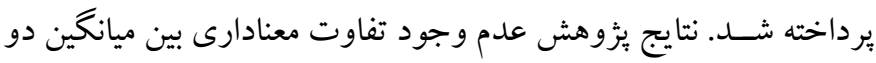

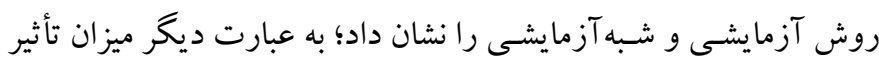

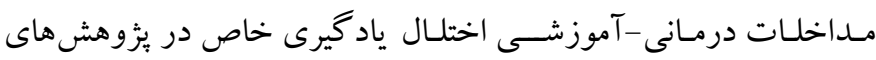
آزمايشـى و شــبه آزمايشـى اختلاف معنادارى ندارد. در تببين اين يافته مى توان كفت كه تفاوتهاى اندك مشــاهده شــــه در اندازههاى اثر به 
انجام شود. از سوى ديخر به علت اينكه فرد با اختلال ياد گيرى خاص در

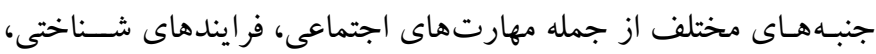

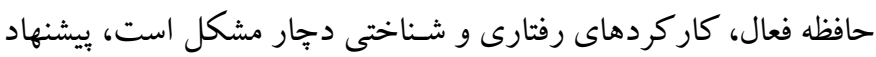

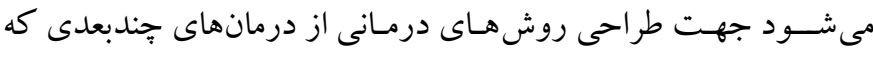

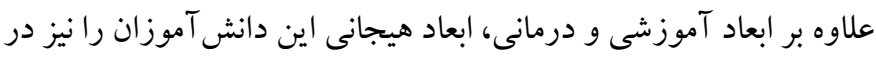

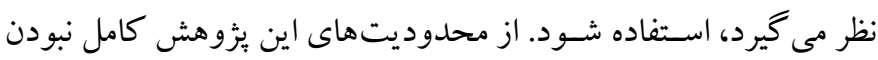

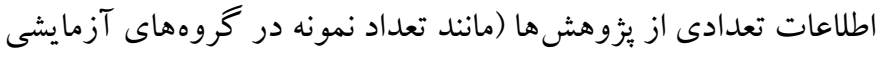

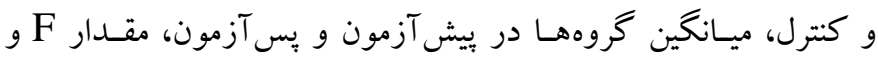

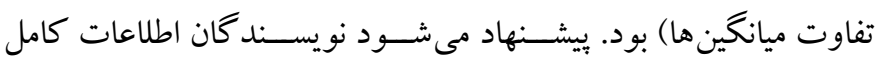
ئزوهشى خود را در مقالات خود درج كنند.

ملاحظات اخلاقى ييروى از اصــول اخلاق ئوهش: اين مقاله بركرفته از ياياننامه دكتراى نويسـنده

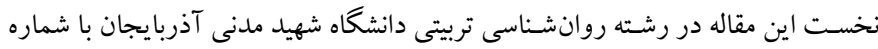

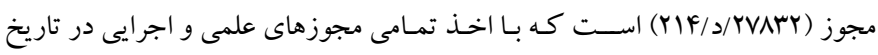
9V/Ir/MN

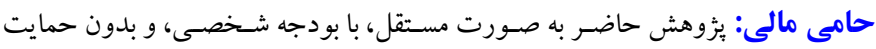
مالى هيج مؤسسه يا سازمان دولتى يا خصوصى انجام شده است.

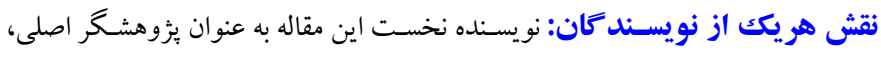
نويسـنده دوم به عنوان استاد راهنما، و نويسند كان سوم و جهارم به عنوان استادان مشاور در اين مطالعه نقش داشتند.

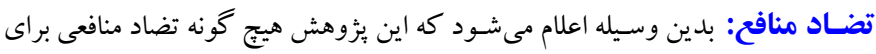

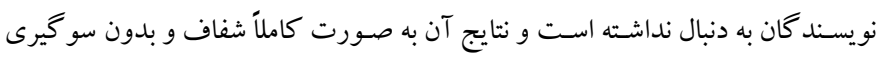
كز ارش شده است. تشـكر و قدردانى: بدين وسـيله از اسـتادان راهنما و مشـاور اين مطالعه و مجموعه افرادى كه به نحوى در روند اجراى اين مطالعه همكارى داشـتهاند، تشـكر و قدردانى
ياد گيرى و ييشـرفت تحصـيلى ندارند. بنابر اين در تبيين اين يافته مىتوان

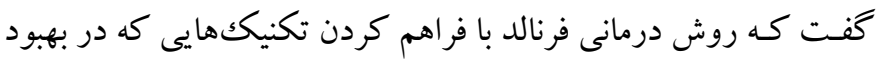

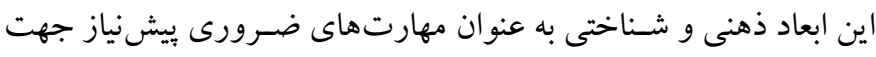

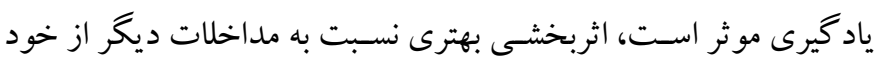
نشان مى دهل. بـدين ترتيب از آن جايى كه ميى توان علائم بالينى و بيشيبنى كننده اختلال يادگيرى خاص را از سـنين كودكى حتى از دو سالكى شناسايى

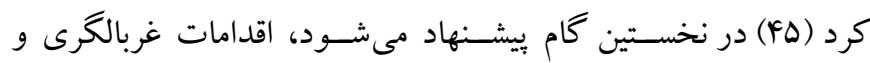

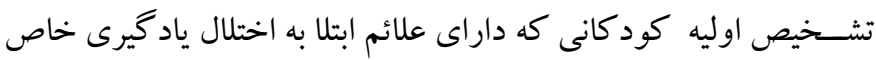

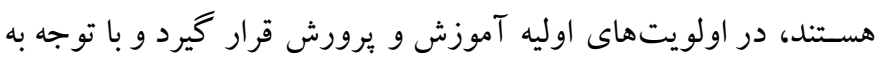
نتايج يزوهش حاضـر مى توان نتيجه كرفت كه جهت طر احى بسـتهـهاى

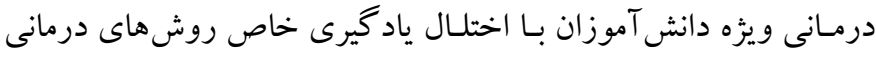

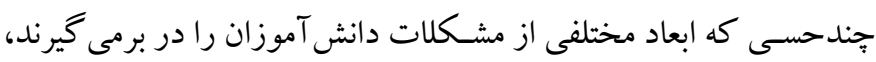
در اولويت هستند. به طور كلى در يُزوهشهاى متعدد، روش هاى مداخـلات آموزشى و

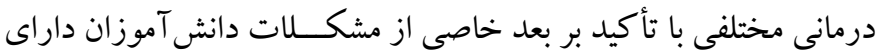

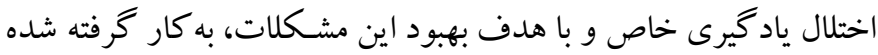

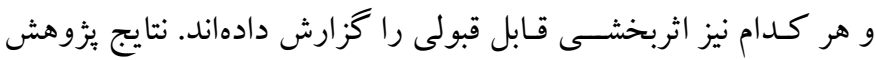

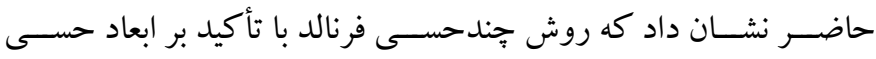

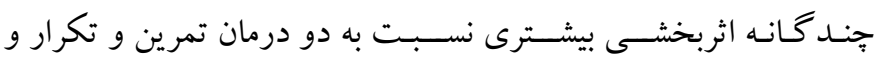

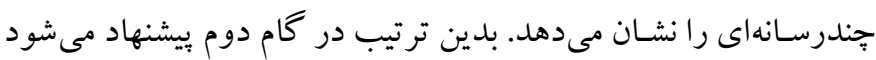

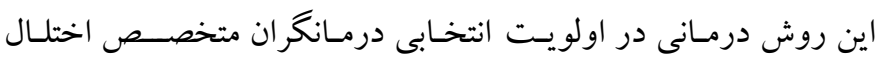
ياد گيرى خاص قرار گيرد. همجنين بيشــنهاد مى شــود مداخلات درمانى - آموزشــى روى

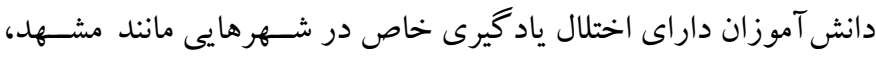

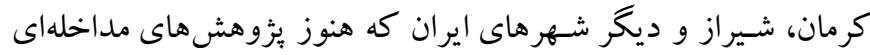

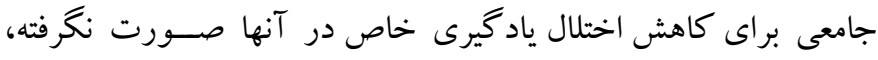




\section{References}

1. Jacob B, Ludwig J. Improving educational outcomes for poor children. National Bureau of Economic Research; 2008; 83. [Link]

2. National Center for Education Statistics. Children and Youth with Disabilities. Retieved Nov 22, 2016, from. [Link]

3. Westendorp, M., Hartman, E., Houwen, S., Huijgen, BC., Smith, J. \& Visscher, C. A. longitudinal study on gross motor development in children with learning disorders. Research in developmental disabilities. 2014; 35(2):357-63. [Link]

4. Fletcher, JM., Lyon GR, Fuchs LS, Barnes MA. Learning disabilities: From identification to intervention. Guilford Publications. 2018; 45. [Link]

5. Hoghughi MS, Long $\mathrm{N}$, editors. Handbook of parenting: theory and research for practice. Sage; 2004 Feb 17. [Link]

6. American Psychiatric Association. APA (2013): Diagnostic and Statistical Manual of Mental Disorders: DSM-5. Aufl. APA-Press, Washington, DC CrossRef Google Scholar. [Link]

7. Scanlon, D. Specific learning disability and its newest definition: Which is comprehensive? And which is insufficient?. Journal of Learning Disabilities. 2013; 46(1):26-33. [Link]

8. Karande, S., Mahajan, V. \& Kulkarni, M. Recollections of learning-disabled adolescents of their schooling experiences: A qualitative study. Indian journal of medical sciences. 2009; 63(9): 382. [Link]

9. Kauffman, JM. \& Hung, LY. Special education for intellectual disability: Current trends and perspectives. Current Opinion in Psychiatry. 2009; 22(5):452-6. [Link]

10. Astramovich, RL., Lyons, C. \& Hamilton, NJ. Play therapy for children with intellectual disabilities. Journal of Child and Adolescent Counseling. 2015; 1(1):27-36. [Link]

11. Mogasale, VV., Patil, VD., Patil, NM. \& Mogasale, V. Prevalence of specific learning disabilities among primary school children in a South Indian city. The Indian Journal of Pediatrics. 2012; 79(3):342-7. [Link]

12. Galuschka, K., Ise, E., Krick, K. \& Schulte-Körne, G. Effectiveness of treatment approaches for children and adolescents with reading disabilities: a metaanalysis of randomized controlled trials. PloS one. 2014; 9(2):e89900. [Link]

13. Jitendra, AK., Lein, AE., Im, SH., Alghamdi, AA., Hefte, SB. \& Mouanoutoua, J. Mathematical interventions for secondary students with learning disabilities and mathematics difficulties: A metaanalysis. Exceptional Children. 2018; 84(2):177-96. [Link]

14. Johnson, ES., Humphrey, M., Mellard, DF., Woods, K. \& Swanson, HL. Cognitive processing deficits and students with specific learning disabilities: A selective meta-analysis of the literature. Learning Disability Quarterly. 2010; 33(1):3-18. [Link]

15. Friso-van den Bos, I., van der Ven, SH., Kroesbergen, EH. \& van Luit, JE. Working memory and mathematics in primary school children: A metaanalysis. Educational research review. 2013; 10:2944. [Link]

16. Kudo, MF., Lussier, CM. \& Swanson, HL. Reading disabilities in children: A selective meta-analysis of the cognitive literature. Research in developmental disabilities. 2015; (40): 51-62. [Link]

17. Gates, JA., Kang, E. \& Lerner, MD. Efficacy of group social skills interventions for youth with autism spectrum disorder: A systematic review and meta-analysis. Clinical Psychology Review. 2017; 52:164-81. [Link]

18. Shamsi A., Abedi A., Samadi M., Ahmadzadeh, M. The meta-analysis of the effectiveness of psychological and educational interventions on improving the academic performance of students with learning disabilities. Journal of Learning Disabilities, 2013; 2(4): 61-81. [Pesian]

19. Sayadatian, S. \& Qamrani, A. Meta-analysis of psychological-educational interventions effectiveness on academic performance of dyslexic students. Journal of Learning Disabilities 2013; 3(2): 42-62. [Persian]

20. Malekian, F. \& Akhoondi, A. The Effect of Multimedia Instruction on Spelling Disability Treatment of the Primary School Students with Specific Learning Disability. Quarterly Journal of New Thoughts in Education. 2010; 1(6), 145-162. [Persian]

21. Heidari, A., Hafezi, F. \& Dezfuli, T. The Effect and Comparison of Frnalde Multidimensional Therapeutic and Cognitive Movement Cards in Reducing Dictation Disorders. New Findings in Psychology. 2009; 4(12):78-65. [Persian]

22. JenaAbadi, $H$. Effect of Kapart and Sina rehabilitation methods in the treatment of reading disorder. Journal of Educational Psychology. 2008; 5 (1), 26-15. [Persian]

23. Shahni, M., Karami, J., Shokrkon, H. \& Mehrabizadeh Honarmand, M. Epidemiology of 
spelling learning disability in elementary school students and students and the effect of multidimensional therapies on reducing the spelling learning disability in them. Journal of Educational Sciences and Psychology. 2004; 3 (9): 129-144. [Persian]

24. Nourizadeh, N., Mikayali, F., Rostami, R. \& Sadeghi, $\mathrm{V}$. Effect of neurofeedback on learning disorder with attention deficit / hyperactivity disorder. Journal of Learning Disabilities, 2012; 2(2): 123-158. [Persian]

25. Mandani, B., Sazmand, A., Farahbod, M., Karimlou, M. The Effects of Occupational Therapy Interventions on the Visual-Motor Integrity of Children with Learning Disabilities. Research in Exceptional Children, 2007; 7 (4): 449-466. [Persian]

26. Abedi, A., Pirooz Zijerdi, M. \& Yarmohammadian, A. The effectivness of training attention on mathematical performance of students with mathematics learning disability. . Journal of Learning Disabilities, 2012; 2 (1): 92-106. [Persian]

27. Mohammadi, F. \& Karami, J. Assessing the effectiveness of Fernald's multidimensional approach to the problem of reading. The first regional mental health conference in elementary school. 2011; 18(1): 270-250. [Persian]

28. Heydari, T, Shahmiveh Esfahani, A., Abedi, A. \& Bahramipour, M. Comparison of the Effect of Freundl and Davis on Reading Performance of Dyslexic Students. Knowledge and Research in Applied Psychology, 2012; 13 (2): 42-34. [Persian]

29. Mohammadi, F., Karami, J. \& Hashemi, T. The effect of Freundlich's multidisciplinary education and practice and repetition in improving the disordered learning of reading primary school students. Journal of Psychological Achievements, 2011; 4 (1): 190169. [Persian]

30. Mansour Nezhad, Z., Kajbaf, M. \& Molavi, H. The effect of Frenald's multidisciplinary education on disadvantages and spellings in elementary school students. New Findings in Psychology. 2012; 7 (24): 111-99. [Persian]

31. Mohammadi, F., Karami, J. \& bayrami, M. The Effectiveness of Homework Approach in the Treatment of Mental Disability. Journal of Research in Psychology, Tabriz University. 2008; 3 (10): 129107. [Persian]

32. AghaBabai, S, Malekpour, M. \& Abedi, A. The Effectiveness of Educational Exercises on the Academic Performance of Children with Spelling
Learning Disabilities. Quarterly Journal of Cognitive Science, 2012; 14 (2): 72-63. [Persian]

33. Abdollahi, S., Kian Ersi, F. \& Rahimian, I. Designing a multimedia educational package emphasizing the basic skills of learning and its effectiveness in reducing the symptoms of dysgarda disorder. Magazine Learning Disabilities. 2013; 3 (3): 54-38. [Persian]

34. Heidari T., Amiri SH. \& Molavi H. Effectiveness of DAVIS Dyslexa Correction Method on Reading Performance of Dyslexic Children. Journal of Applied Psychology. 2012, 2 (22). 41-58. [Persian]

35. Shayan, N., Akhavan Takhti, M. \& Ashayeri, H. The Effect of Davis's Restorative Therapy on Dyslexia. Journal of Educational Psychology. 2011; 7 (12): 23 46. [Persian]

36. Yavari, M. Yaryari, \& Rastegarpour, H. The Utility of a Computer-assisted Instructional Software(Hesabyar) for Teaching Mathematics to Students with Dyscalculia, Journal of Exceptinal Children. 2006, 6 (3), 713-734. [Persian]

37. Estaki, M., Ashayeri, A., Tabrizi, M. \& Delaware, A. Comparison of the Effectiveness of Two Methods of Learning Two Semiconductors and Music Training in Improving the Performance of Female Student Failure Accounts. Research in the field of exceptional children. 2007; 7 (4): 488-425. [Persian]

38. Pourahmadali, A. \& Mousavi Pour, S. Educational multimedia production and its effectiveness on the academic achievement of divorce and division of female students with learning disabilities. Journal of Learning Disabilities. 2014; 3 (3): 37-25. [Persian]

39. Asli Azad M., Yarmohamadeian, A. The Effect Of Metacognition Training And Perception Of Spatial Relationship On Improvment Of Mathematical Operation In Children With Mathematics learning disabilities. Clinical Psychology. 2012, 2(14). 61 To 70. [Persian]

40. Khodami, N., Abedi, A. \& Atashpour, h. Effectiveness of teaching executive functions on improving the performance of students with learning disabilities. New Findings in Psychology. 2010; 5 (17): 77-63. [Persian]

41. Yarmohammadian, A. \& Asl Azad, M. The Effect of Metacognitive Training on Improving the Mathematical Performance of Children with Mental Disability. Quarterly Journal of Cognitive Science, 201214 (1), 25-14. [Persian]

42. Ghobari, B., Nosrati, D. \& Golam Hosseinzadeh, H. The effect of self-instruction on mathematic problem solving performance. 2014, 3 (3), 55-67. [Persian] 
43. Azimi, I. \& Mousavi pour, s. Multicultural production of dictation and its effectiveness on academic achievement of second grade students with spelling learning disabilities in Arak city. Magazine Learning Disabilities, 2014; 4 (1): 88-73. [Persian]

44. Kaufman, J., Hullahan, D. Learning disabilities (foundations, characteristics, and effective teaching). Translation by Dr. Hamid Alizadeh. Tehran: Arasbaran Publications. 2014. [Persian]
45. Zakopoulou, V., Anagnostopoulou, A., Christodoulides, P., Stavrou, L., Sarri, I., Mavreas, V. \& Tzoufi, M. An interpretative model of early indicators of specific developmental dyslexia in preschool age: A comparative presentation of three studies in Greece. Research in developmental disabilities. 2011; 32(6):3003-16. [Link] 